\title{
Students' Soft Skills, Hard Skills, and Competitiveness (SHC): A Suggested Model for Indonesian Higher Education Curriculum
}

\author{
Hadiyanto, Noferdiman, Syamsurizal and Muhaimin \\ Universitas Jambi, Kota Jambi, Indonesia \\ https://orcid.org/0000-0003-4697-9544 \\ https://orcid.org/0000-0002-9446-6359 \\ https://orcid.org/0000-0002-5277-0205 \\ https://orcid.org/0000-0002-6269-5931 \\ Ina Krisantia \\ Universitas Trisakti, Jakarta, Indonesia \\ https://orcid.org/0000-0002-9982-686X
}

\begin{abstract}
This study develops a model for students and graduates of Soft Skills, Hard Skills, and Competitiveness (SHC) and seeks user validation after the development process. The development process uses the Analysis, Design, Development, Implementation, and Evaluation (ADDIE) model. A quantitative survey using questionnaires and descriptive quantitative analysis was applied in obtaining user validation as the study objective. The development results validated the students' SHC Development model, which has 3 main phases, including Input, Process and Output. The Input phase comprises course content, SHC component, and strategy of students' center approach. The Process phase consists of blended course design, instruction and students' engagement, and evaluation. The Output phase comprises soft and hard skills achievement, as well as students' competitiveness level. Users perceived the model's phases and components as wholly acceptable, appropriate, and applicable for implementation through curriculum, teaching, and learning at the university. This study contributes to graduate preparation for employability skills in the challenging and complex working environment in revolution industry 4.0.
\end{abstract}

Keywords: 21st Century Skills; lifelong learning; employability; entrepreneurship; revolution industry 4.0

\section{Introduction}

Higher Education in Indonesia is facing unprecedented challenges arising from the convergent impacts of the Asian Societies Market. Higher education is a growth engine for triggering a country to meet the current needs and prepare for 
future challenges. The issue is related to HE curriculum changes and the fresh graduates' ability to compete in Asian job market, meet employer's expectations, adapt and update their competencies beyond today's challenges. The fresh graduates' competencies should be gained during their university education, embedded with the curriculum and its implementation.

Graduates' competencies in the present study were developed based on current global skills understanding at the workplace, known as the 21st-century skills. The terms used might differ across countries and disciplines, but the essential issues remain the same, such as generic, adaptive, key, soft, life, professional, and interpersonal skills. The researchers, employers, policymakers, and academicians agree that students should acquire these skills at the university and apply them at the workplace to meet the global enterprise needs (Rajadurai et al., 2018; Lippman et al., 2015; Bialik et al., 2015; ILO, 2014).

In line with the studies, the Indonesian Ministry of Science Technology and Higher Education via DIKTI (2016) launched the Guidance of Higher Education Curriculum that demanded universities to provide students with more soft skills than hard skills. Hard skills are acquired and developed through soft skill practices in the teaching and learning process. According to DIKTI (2020), the paradigm of Independent Learning and Independent Campus was launched by the Ministry of Education to provide students with soft and hard skills more than academic competence. Therefore, students are expected to possess individual competitiveness in the job market and their future career development. However, there is no clear guidance in developing graduate's Soft skills, Hard skills, and Competitiveness (SHC) in Universities unless incorporated into teaching and learning.

DIKTI (2020), Thomas (2016), Bialik et al. (2015), and Ahlstrom et al. (2014) suggested that the development of students' hard and soft skills should be blended in the teaching and learning process. Learning strategies should provide the students with $\mathrm{SHC}$, though this is not easy. The problem is how learning activities enable students to gain soft skills through the teaching and learning strategy. In solving this problem, a model was developed as a grand learning concept at an Indonesian University. The model guides the teaching of subjects that develop students' soft and hard skills and competitiveness. However, the defining and the concept were reviewed and found to follow the global trend of university curriculum and employability skills. This explains why the concept contributes to anticipating global issues, such as the lack of graduate employability skills and its combination in the teaching and learning process. Therefore, this study describes and discusses the process and outcomes of the model for developing students' and graduate Soft skills, Hard skills, and Competitiveness (SHC) at a University in Indonesia.

\subsection{Concept Students SHC Development from Curriculum into Teaching and Learning Practice}

Indonesian Ministry of Education and Culture announced a new paradigm of Independent Learning and Independent Campus. The paradigm changes the learning delivery strategy to be more independent and involves some industries 
as students' learning field work. Furthermore, the paradigm regenerates the previous curriculum that emphasis on students acquiring soft and hard skills through their learning strategy. Indonesia's higher education curriculum does not mention specific components of soft and hard skills, and competitiveness. However, the learning objectives are mentioned as developing students' hard skills, soft skills, and competitiveness. The mentioned soft skills include professionalism, communication, decision-making, problem-solving, critical thinking, and another similar attribute understood globally (DIKTI, 2020; DIKTI, 2016; DIKTI, 2016). Theoretical analysis was conducted in this study to draw the students' SHC Development Model. Related studies and resources showed that students' SHC development in universities is conceptualized into the input, process, and output phases discussed in the following section.

\subsubsection{Input Phase}

Input phases are connoted with teachers' preparation to define learning material, students' soft and hard skills, and delivery method. Learning material and content of hard skills should be selected based on students' needs and 5 years latest resources. The delivery method should be selected to allow students to practice and develop their SHC (Adreeva et al., 2020). SHC is defined at the beginning based on the program curriculum that could be integrated with learning material and course design and practiced by students within and outside the classroom (Hadiyanto, 2020; Caggiano, Loredana \& Jerónimo, 2020).

Student-Centered Learning (SCL) is the most appropriate and popular approach to engaging students in obtaining qualified graduates. This regards the teaching and learning approach in developing students' soft and hard skills and competitiveness. SCL facilitates the students to acquire subject knowledge and hard and softs skills during the learning process (Hadiyanto et al., 2021; DIKTI, 2016). The SCL approach is dominated by constructivism theories in which students are allowed to practice individually and in groups. Students think and solve problems, communicate ideas, use IT, and work with other members of the class. However, giving students this opportunity does not mean teachers do not control the students' in-class activities. Instead, the teachers need to develop the main guidelines of learning activities to achieve the set goals (UPI, 2020; DIKTI, 2016; Bialik, 2015).

The teachers' SCL strategies include blended, inquiry, cooperative, collaborative, problem-based, and laboratory learning, as well as E-learning Usage. Suitable learning strategies are selected based on their appropriateness with course topics and students' interests. The strategy should encourage students to practice their soft skills actively and explore and acquire hard skills (Khalil \& Elkhider, 2016).

\subsubsection{Process Phase}

The students' SHC development should start from the syllabus and learning scenario by including soft and hard skills and competitiveness. The learning design, goals, and objectives for students' engagement and activities are process phase that should be considered for promoting soft and hard skills and competitiveness (Andreeva et al., 2020; Novikova, 2016; Bialik et al., 2015). A 
good learning process involves students actively communicating, searching, using ICT, discussing, working together, self-reflecting, learning from others, and achieving goals. A course design is part of the learning process essential in learning and enabling students to practice soft and hard skills. Therefore, the course design should be flexible, revisable, and reflective during the learning process. Moreover, it should be exposed to the students at the first lecture meeting to assess its applicability and make necessary revisions to meet the students' needs and avoid possible handicaps. The delivery method could be planned between the first and second week, and some improvement is made based on the previous reflection. This explains why the course design comes during the process and not at the beginning or during education input (Hadiyanto, 2020).

The SCL learning approach should be conducted through a social process, such as students' interactions, activities, and engagement. Teachers should encourage students to participate actively and contribute to their learning activities. Therefore, the SCL learning methods, such as group projects, field visits, selflearning, exploring, and presentation, are applicable under some strategies mentioned in the input phase. For instance, allowing students to present their work is a popular method applied in teaching and learning. It allows students to share and communicate ideas, learn to attract attention, develop self-confidence before many people, and other related skills (The Ontario Public Services, 2016; Marando, 2012)

Students' soft and hard skills are developed during learning, meaning teachers should use the strategy to guide the students in the right way. This requires the teachers' creativity and critical thinking to design, implement and facilitate the learning activities based on students' competencies, knowledge and skill development. However, Hadiyanto et al. (2017) and Burce \& O'Sullivan (2014) stated that teaching strategies must match the learning goal, and the expected hard and soft skills. DIKTI (2016), Hadiyanto et al. (2021), and Ahlstrom et al. (2014) showed that the teachers' principles that facilitate students to gain knowledge and skills include:

a. Understanding how students learn

b. Matching the learning and teaching principles

c. Facilitating rather than control learning

d. Motivating and encouraging students to interact in learning actively

e. Assuring the practice of soft skills and acquisition of hard skills.

f. Promoting and expecting student accountability for learning

g. Providing timely, specific feedback on learner progress

$h$. Individualizing learning experiences based on needs

Students' SHC is developed during the teaching and learning process. Therefore, SCL should apply in syllabus, lesson plan, and learning process to construct student' SHC. Furthermore, teachers suggested applying teaching and learning strategies to optimize the gaining of soft and hard skills. Therefore, SHC students' SHC self-evaluation and rubrics assessment could be developed based on theoretical analysis of SHC and academician judgment (Cimatti, 2016). 


\subsubsection{Output Phases}

Literature reviews show that Higher Education across countries agrees that university graduates should develop high soft and hard skills and competitiveness. The graduate should be ready to work on global and digital challenges, promote self-expertise and continue learning to improve their quality, impacting institutional and national competitiveness (Hadiyanto, 2020; DIKTI, 2020; UPI, 2020). Moreover, the graduate should be attributed soft and hard skills based on employee recruitment, employers' interview, Indonesian curriculum and higher education paradigm. In this case, students' competitiveness level is the outcome of soft and hard skills.

This study defines Soft Skills, Hard Skills, and Competitiveness (SHC) as a blended ability to achieve an objective (Hadiyanto et al., 2017; Andreeva et al., 2020; Novikova, 2016). Universities help students to develop soft and hard skills, which determine their competitiveness. Soft Skills are essential in the global work market and are practiced in learning activities. Also, they are practiced at workplaces through communication, IT, numeracy, learning, problem-solving skills, and working with others. Soft skills are developed during the learning process within or outside the campus and at the workplace. The practice of soft skills generates and develops students' hard skills in their disciplines (Hadiyanto, 2017, Khalil \& Elkhider, 2016, UNJA, 2014).

Communication Skills involve expressing and exchanging ideas using feelings of thought and verbal and non-verbal media, including speech and written text (Khalil \& Elkhider, 2016).

IT Skills are one's ability to use digital technology of computers, integrated devices, and necessary applications for working. These applications include Microsoft Office, Internet Browser, E-mail, Messenger, Online Meeting, Digital File Manager, and Network (Hadiyanto et al., 2021; Burce \& O'sullivan, 2014). Numeracy Skills are the ability to use basic mathematic calculation, interpreting graphical information, timing, prioritizing tasks, and sequencing of job or activities (Balcar, Šimek \& Filipová, 2018; Hadiyanto et al., 2017). Learning Skills are the ability to use strategies, evaluate the self-learning strategy, seek weaknesses, and develop better learning output. This includes gaining general and detailed information, knowledge, and skills to achieve the goal of learning (Hadiyanto et al., 2017; Alberta Education. 2011; Jones, 2009).

Problem-solving skills involve the ability to systematically tackle problems to develop an appropriate solution (Lippman et al., 2015; Ahlstrom et al., 2014). Team-work skills are the capacity to interact effectively with other people individually and in groups. This includes understanding and responding to a client's needs and working effectively as a team member to achieve a goal (Luara et al., 2016; Ahlstrom et al., 2014; ILO, 2014). Hard Skills are the ability to apply and generate specific knowledge and skills in real context and work. Students acquire hard skills to practice their softs skills, such as presentation, discussion, and using applications for working out assignments and group projects (Ahlstrom et al., 2014, Marando, 2012 and Chan, Goh \& Priest, 2015). 
Competitiveness is the eagerness and the effort to consistently apply, maintain, improve and promote soft and hard skills in work, tasks and learning. It is categorized into lifelong learning, entrepreneurship, and employability. Competitiveness was assumed to be affected by soft and hard skills (Balcar et al., 2018; Kumar, 2017; UNJA, 2020; Novikova, 2016). Entrepreneurship is the ability to apply soft and hard skills in creating, promoting, proposing, building, exploring, seeking, and offering business opportunities and services based on expertise (UNJA, 2020; DIKTI, 2020; Balcar et al., 2018; Liventsova, Rumyantsevaa \& Syriamkina, 2016). Lifelong learning is the eagerness and willingness to learn beyond what someone knows currently. Furthermore, lifelong learning involves developing beyond current capacity to meet future challenges using multi-resource and comparing resources, friends, environment, and ICT (Hadiyanto et al., 2017; DIKTI, 2016; Bialik et al., 2015).

Employability is the ability to apply specific skills, subject knowledge, and standard quality of a graduate. It comprises certain competencies to adapt and meet the changing needs of employers and customers and the ability to be selfemployed (DIKTI, 2020: UPI 2020; Liventsova et al., 2016: Bialik et al. 2015).

\section{Research Methodology}

The model of Students SHC was developed through research and development. The development phases and steps were adapted from the ADDIE model by Branch and Robert Maribe (2009), Richey and Klein (2007), and Dick, Carey and Carey (2001). The main development phases applied included Analysis, Designing, Developing, Implementing, Evaluation, and Revision. Mixed-mode Quantitative and Qualitative methods were applied in some parts of the model development process. The instruments used were literature reviews, questionnaires, interviews, SHC assessment rubrics, FGD Protocol, and documentaries. The study used 3 groups of participants, including stakeholders, lecturers, and students.

\subsection{The Phase of Model Development}

The first phase is the analysis of previous research and publication, HE curriculum, Vision and Mission, and strategic plan of the University of Jambi (Unja, 2020). Also, there was a survey on students' needs, current literature review, stakeholders' system recruitment, and interview. The second phase involved designing, which included categorizing and defining SHC components. Moreover, there were designing phases and features of students' SHC development in the learning process and strategy. The third phase involved developing a student's SHC Development model, which comprises Input, Process, and Output. Furthermore, the phase involved the expert, users, and try-out validations. The fourth phase involved the implementation in 4 faculties, while the last phase was evaluation and revision.

\subsection{Participants of the Study}

There were 26 lecturers that participated in the study, representing Economics and Business, Teacher Training and Education, Animal Husbandry, Science Technology, and Humanities Faculty. A total of 773 students across the faculties 
were involved, with 513 as questionnaire respondents, while 250 participated in experimental research. Furthermore, 5 people representing stakeholders participated in FGD.

\subsection{Validator of the Development Process}

This study used 3 external and 4 internal expert validators to assess and contribute to the model's improvement. In particular, 2 external validators were from Universitas Brawijaya, with expertise in curriculum, teaching, and learning Science at University. One external validator was from Universitas Negeri Yogyakarta, having expertise in the higher education curriculum. Moreover, the 4 internal validators were from various disciplines, one was a professor and expert in R \& D. Of the other 3 validators, the first was an expert in chemistry education, the second in psychology education, while the third had expertise in agriculture learning at the university. Qualitative reviews were addressed by all validators related to contents, design of the model, components, and phases of students' SHC Development.

\subsection{Sampling for User Validation}

User validation was conducted in the last phase of the study after revision. Stratified random sampling was used to select the samples among the Universities' teaching staff. It involved distributing the questionnaires to 5 faculties, including Economics and Business, Teachers Training and Education, Agriculture, Animal Husbandry, and Science Technology. Each faculty was provided with 50 questionnaires, resulting in a total of 250 questionnaires. Out of this total, 216 questionnaires were returned. The survey aimed at evaluating user acceptance, appropriateness and applicability of the model. This included phases and components of students' soft and hard skills, as well as competitiveness development.

\subsection{Method and Instrumentation}

A quantitative method was applied in investigating user validation. The instrument was developed and justified through a qualitative approach, literature review analysis, workshop among the research team, and piloted to 20 teachers. Reliability was measured by a consistency test. Pallant (2011) and Hair et al. (2009) suggested that Cronbach alpha coefficient ( $\alpha$ ) .60 for a construct comprises a maximum of 10 items, while coefficient .70 means the construct consists of more than 10 items. The consistency test resulted in a above .60 for components with a maximum of 10 items, and a above .70 for components with more than 10 items. Acceptance of Model Arrangement in General comprising 5 items yielded a .605, appropriateness of SHC component a .804, the applicability of SHC component a .743, appropriateness of phases SHC development a .819 and applicability of phases SHC development a .780.

\subsection{Data Analysis of User Validation}

Descriptive analysis was applied in which the mean and standard deviation values were used to report the findings. The interpretation of the means score was as follow;

$1.00-1.80=$ Strongly Unacceptable, Inappropriate (SI), or Inapplicable (SIP) 
$1.81-2.60=$ Unacceptable, Inappropriate, or Inapplicable

$2.61-3.40=$ Fair

$3.41-4.20=$ Acceptable, Appropriate, or Applicable

$4.20-5.00=$ Strong Acceptable, Appropriate (SA), or Applicable (SAP)

\section{The Study Results}

\subsection{Result of Model of Students SHC Development}

The students' SHC Development model at a University should be started and integrated with the curriculum, course design, syllabus, lesson plan, as well as offline and online learning. Students SHC is developed in blended learning activities in every course of a program. This model was justified by global literature studies and is divided into Input, Process, and Output phases.

\subsubsection{Input}

The Input phase involves planning and preparation before implementing students' SHC Development Model into the teaching and learning process. In this phase, teachers should search hand-outs, materials, and resources for course content and consider components of soft and hard skills to be integrated into the syllabus and course design. Additionally, the delivery method and strategies should be defined to match the materials, hand-outs, and expected SHC outcomes.

\subsection{2. $\quad$ Process}

The process phase is an implementation of students' SHC Development through the teaching and learning process. The syllabus and lessons plan unit was developed in this phase. The SHC components, delivery method and strategy, and teachers' guidelines should be clearly stated in the syllabus and lesson plan. Moreover, teachers need to act the lesson plan during class activities. Students are facilitated and guided to actively acquire soft and hard skills by interacting, discussing, exploring, and using multi-resources based on the lesson plan. Also, teachers must observe students' practice of soft and hard skills.

\subsubsection{Output}

The output phase involves assessing the students' achievement based on SHC standards. Students are expected to gain certain SHC levels through teaching and learning within a semester. Students' self-evaluation questionnaire and SHC rubric assessment (Hadiyanto et al., 2017) are used to measure the level of SHC. Theoretically, high students' soft and hard skills increase their competitiveness (Setiawan et al., 2020) 


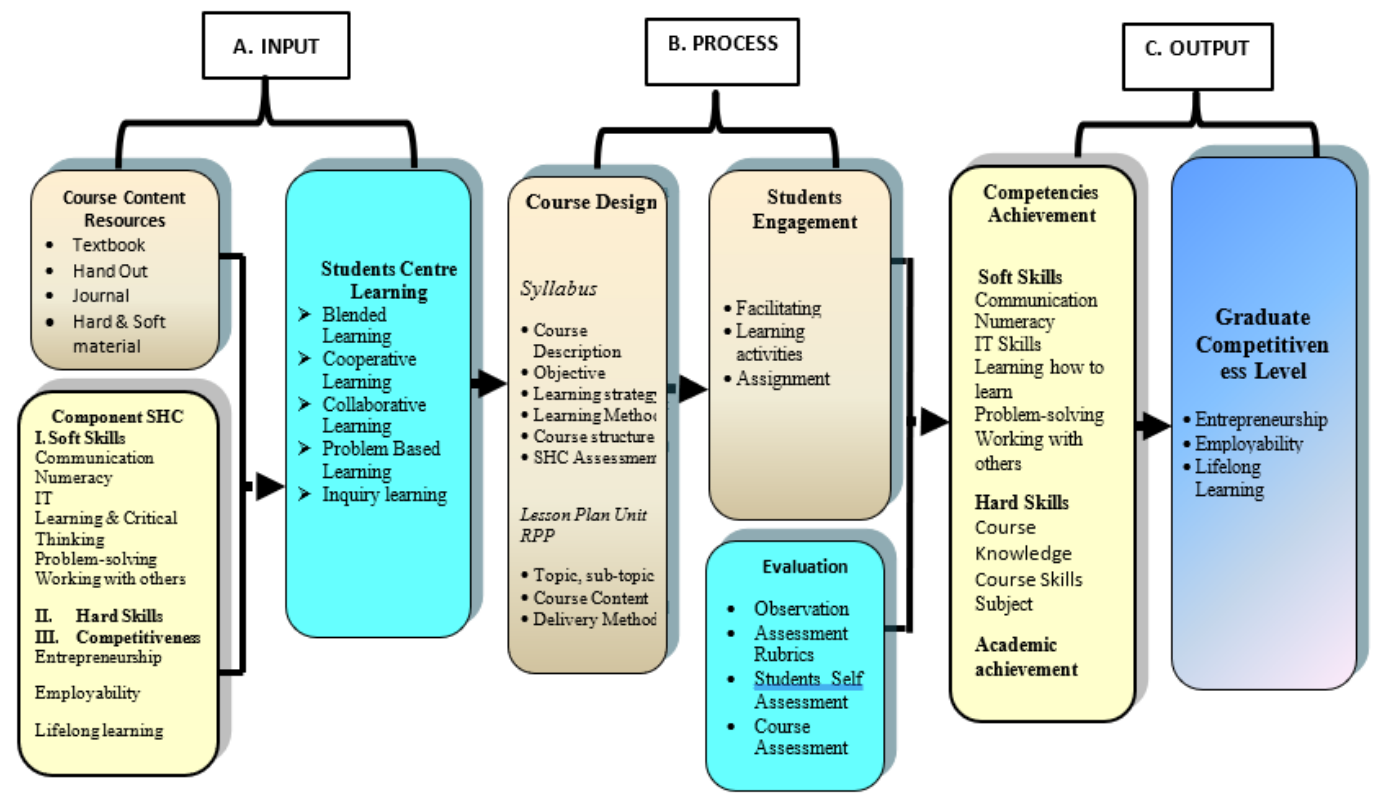

Figure 1: Model of Students' SHC Development at A University in Indonesia (DIKTI, 2020; UNJA, 2020; UPI, 2020; Hadiyanto et al., 2017; Lippman et al., 2015; DIKTI, 2016; Bialik et al., 2015)

\subsection{Result of A survey of User Validation of the Model}

The results show that the overall arrangement of SHC Model development is acceptable. Furthermore, teachers perceived that the model's arrangement into Input, Process, Output, and Layout indicated by arrows and lines is strongly acceptable. The other 3 elements were Arrangement of Part of Input, Process, and Output perceived as acceptable. Moreover, teachers, components under input, process and output, and Implementation flexibility were rated as acceptable. These findings implied that students SHC model development is acceptable by teachers, as shown in Table 2 :

Table 2: Overall Model Arrangement in General

\begin{tabular}{|l|l|l|l|l|l|}
\hline $\begin{array}{l}\text { A. Acceptance of Model } \\
\text { Arrangement in General }\end{array}$ & Min. & Max. & Mean & S.td & Level \\
\hline $\begin{array}{l}\text { 1. Arrangement of Model; Input, } \\
\text { Process, and Output }\end{array}$ & 3,00 & 5,00 & 4,21 &, 695 & SA \\
\hline $\begin{array}{l}\text { 2. Arrangement of Part of Input, } \\
\text { Process, and Output }\end{array}$ & 3,00 & 5,00 & 4,13 &, 542 & Acceptable \\
\hline 3. Layout, indicating arrow and lines & 3,00 & 5,00 & 4,23 &, 59 & SA \\
\hline $\begin{array}{l}\text { 4. Arrangement of components } \\
\text { under input, process and output. }\end{array}$ & 3,00 & 5,00 & 4,06 &, 570 & Acceptable \\
\hline 5. Flexibility for Implementation & 3,00 & 5,00 & 3,97 &, 483 & Acceptable \\
\hline Overall & 3,20 & 5,00 & 4,12 &, 353 & Acceptable \\
\hline
\end{tabular}

Respondents rated the overall component under SHC as appropriate. Also, soft skills and competitiveness of SHC components were rated as appropriate. Both mean scores were close to strongly appropriate, while the hard skills component was rated as strongly appropriate. Based on specific components of soft skills, 
communication, IT, working with others was rated as strongly appropriate. Numeracy, problem-solving, and working with others were rated as appropriate. Specific knowledge as one of the hard skills components was rated as strongly appropriate, while specific skills were rated as appropriate, with a mean score of 4.17 , which was very close to strongly appropriate. The 2 specific competitiveness components, entrepreneurship, and employability were rated as appropriate, while lifelong learning was rated as strongly appropriate, as shown in Table 3:

Table 3: Appropriateness of SHC Component

\begin{tabular}{|l|c|c|c|l|l|}
\hline B. Appropriateness of SHC Component & Min. & Max. & Mean & S.td & Level \\
\hline a. Soft Skills & & & & & \\
\hline 1. Communication & 3,00 & 5,00 & 4,24 &, 537 & SA \\
\hline 2. Numeracy & 3,00 & 5,00 & 4,05 &, 524 & Appropriate \\
\hline 3. IT & 3,00 & 5,00 & 4,35 &, 547 & SA \\
\hline 4. Problem Solving & 3,00 & 5,00 & 4,07 &, 440 & Appropriate \\
\hline 5. Learning How to learn & 3,00 & 5,00 & 4,08 &, 428 & Appropriate \\
\hline 6. Working with others & 3,00 & 5,00 & 4,22 &, 458 & SA \\
\hline$\quad$ Overall & 3,33 & 5,00 & 4,17 &, 339 & Appropriate \\
\hline b. Hard Skills & & & & & \\
\hline 1. Specific knowledge & 3,00 & 5,00 & 4,27 &, 520 & SA \\
\hline 2. Specific skills & 3,00 & 5,00 & 4,17 &, 480 & Appropriate \\
\hline$\quad$ Overall & 3,10 & 5,00 & 4,22 &, 439 & SA \\
\hline c. Competitiveness & & & & & \\
\hline 1. Entrepreneurship & 3,00 & 5,00 & 3,77 &, 512 & Appropriate \\
\hline 2. Employability & 3,00 & 5,00 & 4,13 &, 454 & Appropriate \\
\hline 3. Lifelong Learning & 3,00 & 5,00 & 4,21 &, 490 & SA \\
\hline$\quad$ Overall & 3,05 & 5,00 & 4,04 &, 363 & SA \\
\hline SHC Component Appropriateness & 3,64 & 4,91 & 4,14 &, 283 & SA \\
\hline
\end{tabular}

\subsection{Applicability of SHC Component}

Respondents rated the overall applicability of components under SHC as applicable. Overall Hard skills were rated as strongly applicable, while Soft skills and competitiveness were rated as applicable. All mean scores of the components were close to strongly applicable or at the top of the applicable mean. Based on specific components of soft skills, IT was rated as strongly applicable, while communication and working with others were rated as strongly appropriate. Numeracy, problem-solving, and working with others were rated as applicable. As one of the hard skills components, specific knowledge was rated as strongly applicable, while specific skills were rated as applicable. All specific components of competitiveness, entrepreneurship, employability, and lifelong learning were rated as applicable. 
Table 4: Applicability of SHC Component

\begin{tabular}{|l|l|l|l|l|l|}
\hline C. Applicability of SHC Component & Min. & Max. & Mean & S.td & Level \\
\hline a. Soft Skills & & & & & \\
\hline 1. Communication & 3,00 & 5,00 & 4,13 &, 508 & Applicable \\
\hline 2. Numeracy & 3,00 & 5,00 & 3,94 &, 453 & Applicable \\
\hline 3. IT & 3,00 & 5,00 & 4,26 &, 516 & SAP \\
\hline 4. Problem Solving & 3,00 & 5,00 & 3,97 &, 426 & Applicable \\
\hline 5. Learning How to learn & 3,00 & 5,00 & 4,00 &, 406 & Applicable \\
\hline 6. Working with others & 3,00 & 5,00 & 4,17 &, 462 & Applicable \\
\hline$\quad$ Overall & 3,33 & 5,00 & 4,08 &, 312 & Applicable \\
\hline b. Hard Skills & & & & & \\
\hline 1. Specific knowledge & 3,00 & 5,00 & 4,25 &, 477 & SAP \\
\hline 2. Specific skills & 3,00 & 5,00 & 4,17 &, 442 & Applicable \\
\hline$\quad$ Overall & 3,00 & 5,00 & 4,21 &, 400 & SAP \\
\hline c. Competitiveness & & & & & \\
\hline 1. Entrepreneurship & 3,00 & 5,00 & 3,71 &, 507 & Applicable \\
\hline 2. Employability & 3,00 & 5,00 & 4,11 &, 452 & Applicable \\
\hline 3. Lifelong Learning & 3,00 & 5,00 & 4,18 &, 468 & Applicable \\
\hline$\quad$ Overall & 3,33 & 5,00 & 4,00 &, 330 & Applicable \\
\hline SHC Component Applicability & 3,55 & 4,82 & 4,08 &, 247 & Applicable \\
\hline
\end{tabular}

Respondents rated the overall appropriateness of SHC development phases at university as appropriate. Also, the Input, Process, and Output phases were rated as appropriate. Respondents rated the course content and resources of Input phases as strongly appropriate, while the SHC and learning approach components were appropriate. Concerning the Process phase, the course design was claimed as strongly appropriate, while students' engagement and evaluation were rated as appropriate. Respondents rated the elements of the Output phase, competence achievement, and graduate competitiveness as appropriate. The 2 specific components of competitiveness, entrepreneurship, and employability were rated as appropriate, while lifelong learning was strongly appropriate.

Table 5: Appropriateness of SHC Phases Development

\begin{tabular}{|l|c|c|c|c|l|}
\hline $\begin{array}{l}\text { D. Appropriateness of SHC phases } \\
\text { Development }\end{array}$ & Min. & Max. & Mean & S.td & Level \\
\hline a. Input & & & & & \\
\hline 1. Course Content Resources & 4,00 & 5,00 & 4,27 &, 448 & SA \\
\hline 2. Component of SHC & 3,00 & 5,00 & 4,14 &, 461 & Appropriate \\
\hline 3. Learning Approach & 3,00 & 5,00 & 4,13 &, 393 & Appropriate \\
\hline$\quad$ Overall & 3,33 & 5,00 & 4,18 &, 329 & Appropriate \\
\hline b. Process & & & & & \\
\hline 1. Course design & 3,00 & 5,00 & 4,23 &, 444 & SA \\
\hline 2. Students' engagement & 3,00 & 5,00 & 4,10 &, 464 & Appropriate \\
\hline
\end{tabular}




\begin{tabular}{|l|l|l|l|l|l|}
\hline 3. Evaluation & 3,00 & 5,00 & 3,94 &, 557 & Appropriate \\
\hline$\quad$ Overall & 3,00 & 5,00 & 4,09 &, 387 & Appropriate \\
\hline c. Output & & & & & \\
\hline 1. Competencies Achievement & 3,00 & 5,00 & 3,97 &, 426 & Appropriate \\
\hline 2. Graduate Competitiveness level & 3,00 & 5,00 & 4,07 &, 376 & Appropriate \\
\hline$\quad$ Overall & 3,00 & 5,00 & 4,02 &, 328 & Appropriate \\
\hline Overall Phases Appropriateness. & 3,38 & 5,00 & 4,11 &, 298 & Appropriate \\
\hline
\end{tabular}

Respondents rated the phases of students' SHC development as applicable. The Input, Process and Output phases were rated as applicable. Furthermore, respondent rated the course content resources, component of SHC and learning approach as applicable. Based on the Process phase, course design was strongly applicable, while students' engagement and evaluation were rated as applicable. The elements of Output phases, competencies achievement, and graduate competitiveness level were applicable.

Table 6: Applicability of SHC phases development

\begin{tabular}{|l|c|c|c|c|c|}
\hline $\begin{array}{l}\text { E. Applicability of phases SHC } \\
\text { development }\end{array}$ & Min. & Max. & Mean & S.td & Level \\
\hline a. Input & & & & & \\
\hline 1. Course Content Resources & 3,00 & 5,00 & 4,19 &, 461 & Applicable \\
\hline 2. Component of SHC & 3,00 & 5,00 & 4,14 &, 461 & Applicable \\
\hline 3. Learning Approach & 3,00 & 5,00 & 4,09 &, 348 & Applicable \\
\hline$\quad$ Overall & 3,00 & 5,00 & 4,14 &, 305 & Applicable \\
\hline b. Process & & & & & \\
\hline 1. Course design & 3,00 & 5,00 & 4,21 &, 433 & SA \\
\hline 2. Students' engagement & 3,00 & 5,00 & 4,08 &, 448 & Applicable \\
\hline 3. Evaluation & 3,00 & 5,00 & 3,93 &, 548 & Applicable \\
\hline$\quad$ Overall & 3,00 & 5,00 & 4,08 &, 369 & Applicable \\
\hline c. Output & & & & & Applicable \\
\hline 1. Competencies Achievement & 3,00 & 5,00 & 3,96 &, 436 & Applicable \\
\hline 2. Graduate Competitiveness level & 3,00 & 5,00 & 4,04 &, 333 & Applicable \\
\hline$\quad$ Overall & 3,00 & 5,00 & 4,00 &, 305 & Applicable \\
\hline Overall Phases Applicability & 3,13 & 4,88 & 4,08 &, 275 & Applicable \\
\hline
\end{tabular}

\section{Discussion}

Teachers, stakeholders, students, policymakers were involved in developing the $\mathrm{R}$ and D model of Students SHC Development at the university. Cimatti (2016) stated that the university suggested seeking match definitions, model methods, tools, and the soft and hard skills applicable for learning practice. This way would enable the graduate to achieve high employability performance. The students' SHC Development model is conducted in 3 phases, including Input, Process, and Output, and is validated as either internal or external. Internal validation confirms the components and phases of students SHC Development model, while external validation evaluates the impact of the model's products 
use. The users' validation method was excellent in receiving feedback on how the model fits their course (Richey and Klein, 2007).

Teachers accepted the model of students' SHC development in the Input, Process, and Output phases and its layout. Also, they understood the position and the arrangement of the model and accepted the placement and arrow between elements of Input, Process, and Output. Md-Ali, Shaffie \& Yusof (2016) showed that teachers understood and accepted the integration of soft and hard skills in teaching and learning to allow students to develop employability skills.

Teachers perceived that the inclusion of SHC components overall was appropriate. The soft skills and competitiveness of SHC components were appropriate. Both mean scores were close to strongly appropriate, while the hard skills component was strongly appropriate. The 2 specific components of competitiveness, entrepreneurship, and employability were rated as appropriate, while lifelong learning was strongly appropriate. These findings implied that components and sub-component of SHC fit their courses and meet today's challenge in higher education. According to Liventsova et al. (2016), universities worldwide should develop soft skills and competitiveness. Therefore, teachers should be provided with a teaching and learning model that develops students' soft and hard skills to nurture their competitiveness.

Respondents confirmed that the SHC model phases are applicable in teaching their courses. Overall hard skills were rated as strongly applicable, while soft skills and competitiveness were applicable. All mean scores of the sub-skills of SHC were close to strongly applicable or at the top of the applicable, mean score. The phases, SHC, and their components are relevant for implementation in the teaching and learning of all courses at the university. These findings support Caggiano et al. (2020) that HE teachers perceive softs skills as relevant for integration with course skills in implementing curriculum design in Finland, Italy, and beyond. Furthermore, while Andreeva et al. (2019) showed that the students' soft and hard skills application in learning develops their competitiveness.

The students' SHC development model fits with teachers' competence in any field and subject and applicable for the classroom, outdoors, and laboratory learning. According to Patcsil et al. (2017), teaching and learning softs and hard skills should fit the current needs and teachers' competence.

This study guides Higher Education teachers to develop their curriculum design, generate high-quality learning facilities, and assess the students' SHC development activities (Caggiano et al., 2020). Universities should enhance or include the SHC development components in curriculum planning and revision. Curriculum and learning design should be enhanced to improve students' soft and hard skills and increase their competitiveness. Furthermore, according to Novikova (2016), teachers should be facilitated to improve their professional skills. This is because they play a key role in taking creative solutions to enrich the learning process with expressive means and modern educational techniques. 
The research contributes to the theoretical and practical side of the students and graduates with 21st-century skills. Practically, the research contributes to universities because this model was conducted through extensive library research related to 21st-century skills development in the University context. The model focused on the vision, mission, and curriculum of the present university and faculty. This aimed to improve graduates' quality to provide them with the skills needed to compete globally and contribute to the nation (Rajadurai et al., 2018; ILO, 2014). Moreover, the results of R \& D provide answers to academician questions on how to integrate 21st-century skills into the learning design and process. Therefore, universities interested in this model could adapt and integrated it into their situation. This is because the model was developed based on global trends and issues and could be used as guidance or resource.

The model's theory and conceptual framework provide university teachers with choices on the appropriate content delivery method to enable students to achieve learning goals and acquire 21st-century skills (UPI; 2020; Md-Ali et al., 2016). Also, the results show educators that students and graduates with 21stcentury skills are developed through a course teaching and learning that impacts their specific knowledge.

This research adds more theoretical value to the available literature on the concept and model of 21st-century skills and other related definitions. It gives more information on the theory and innovative concept of 21st-century skills implementation in university curriculum and faculty. Furthermore, the research is relevant for revolution industry 4.0 and 5.0 (DIKTI, 2020; Md-Ali, 2016; Cimatti, 2016). Initial implementation should be conducted through some research by a programmer on improving the management and evaluation of the model implementation. Also, classroom action research should evaluate how teachers create, select and apply a learning technique to develop students' SHC. Experimental research should ascertain the model's effectiveness and improve the students' SHC based on this study's definition.

These findings were forwarded to the policymakers of this university. Only a few universities worldwide provide extracurricular training to equip students with SHC. Implementing the university-level model to the teaching and learning process would reduce the number of unskilled graduates. Furthermore, it allows students to acquire SHC acquisition, and graduates contribute to faster development at their workplace (Setiwan et al., 2020; Patacsil \& Tablatin, 2017). Therefore, this research suggests to university policymakers to implement and improve students' SHC development strategies.

\section{Conclusion}

This study developed a model of students' SHC development through teaching and learning process at a University. The results showed that the students' SHC Development model in teaching and learning has 3 main phases, including Input, Process, and Output. The users' validation results proved that the model 
is acceptable, appropriate and applicable for integration and implementation in curriculum and students learning process. Moreover, the model is expected to meet global issues and challenge, and answer questions regarding the low awareness of policy maker at universities on the needs of graduates' SHC capabilities.

Teachers need to reinterpret the SHC development model for possible implementation in their course. This is because the model could become very large when teachers implement it as a whole. For instance, teachers should select the best learning strategy from those stated in the model that fits their course and develops soft skills. Additionally, they need to select the soft skills components that could be implemented and assessed in their course. Other uses of the model could not be adopted in other universities due to certain challenges. Therefore, university curriculum, national orientation, and existing issues in their countries should be considered, and preliminary analysis is conducted. Furthermore, the model could be adjusted and applied in other universities by carefully analyzing the national and university curriculum and literature reviews of current issues and global challenges. A further qualitative and quantitative study should be conducted on the model's innovation, as well as the strategies and effectiveness of its implementation.

\section{Acknowledgement}

The study was funded by RISPRO LPDP PRJ 13/LPDP/2018, Ministry of Finance Indonesia.

\section{References}

Ahlstrom, A. W., Yohalem, N., David, Ji, P., Hillaker, P., \& David, P. (2014). From Soft Skills to Hard Data: Measuring Youth Program Outcomes. New York, USA: William T. Grant Foundation.

Andreeva, E., Khrisanova, E., Gunina, E., \& Vishnevskaya, M. (2020). Psychological and Pedagogical Support for the Formation of Students' Competitiveness in the Educational and Professional Space of the University. International Scientific and Practical Conference on Education, Health and Human Wellbeing Advances in Social Science, Education and Humanities Research, 396, 50-54. https://doi.org/10.2991/iceder-19.2020.11

Balcar, J., Šimek, M., \& Filipová, L., (2018). Soft Skills of Czech Graduates, Review of Economic Perspectives. De Gruyter, Warsaw, 18(1), 45-60, http://dx.doi.org/10.2478/revecp-2018-0003

Bialik, M., Bogan, M., Fadel, C., \& Horyathova, M. (2015). Character Education for the 21st Century: What Should Students Learn? Center for Curriculum Redesign. Boston, USA: Center for Curriculum Redesign.

Branch, R. M. (2009). Instructional Design: The ADDIE Approach. USA: Springer.

Burce, A., \& O'sullivan, N. (2014, September 22-23). Teaching and Learning in Competency-Based Education [Conference paper]. The Fifth International Conference on e-Learning (eLearning-2014). Belgrade, Serbia: Innovative Together Ltd.

Caggiano, K. S., Loredana P., \& Jerónimo G., (2020). Towards Identifying the Soft Skills Needed in Curricula: Finnish and Italian Students' Self-Evaluations Indicate Differences between Groups Valeria. Sustainability, 12(4031), 1-10 http://doi.org/10.3390/su12104031. 
Chan, J., Goh, J., \& Priest, K. (2015). Soft skills, hard challenges: Understanding the nature of China's skills gap. Londong, UK: British Council.

Cimatti, B. (2016). Definition, Development, Assessment of Soft Skills and Their Role for The Quality of Organizations and Enterprises. International Journal for Quality Research, 10(1), 97-130. http:/ / doi.org/10.18421/IJQR10.01-05

Dick, W., Carey, L., \& Carey, J. O. (2001). The systematic design of instruction (5th ed.). New York, USA: Addison-Wesley Educational Publishers.

DIKTI. (2016). Panduan Penyusuanan Kurrikulum Pendidikan. Jakarta, Indonesia: DIKTI.

DIKTI. (2020). Guide Book of Independent learning - Independence of Campus. http://dikti.kemdikbud.go.id/wp-content/uploads/2020/04/Buku-PanduanMerdeka-Belajar-Kampus-Merdeka-2020.

Hadiyanto, Mukminin, A., Failasofah. Arif, N., Fajaryani, N., \& Habibi, A. (2017). In Search of Quality Student Teachers in a Digital Era: Reframing the Practices of Soft Skills in Teacher Education. TOJET: The Turkish Online Journal of Educational Technology, 16(3), 71-78.

Hadiyanto. (2020, September 30 - October 01). Constructing A Prototype of Developing Students' 21st Century Skills; Soft Skills, Hard Skills, and Competitiveness at a University in Indonesia. ICEMS 2019, Jakarta, Indonesia. http://doi.org/10.4108/eai.30-9-2019.2291171

Hadiyanto, Failasofah, Armiwati, Abrar, M., \& Thabran, Y. (2021). Students' Practices of 21st Century Skills between Conventional learning and Blended Learning. Journal of University Teaching \& Learning Practice, 18(3), 7-19.

Hadiyanto, Noferdiman, Moehamin, \& Yuliusman. (2017). Assessing Students And Graduates Soft Skills, Hard Skills And Competitiveness. International Journal of Social Sciences, 3(2), 1885-1906.

ILO. (2014). Survey of ASEAN employers on skills and competitiveness. Emerging Markets Consulting. Bankok, Thailand: ILO.

Khalil, M., \& Elkhider, I. A. (2016). Applying learning theories and instructional design models for effective instruction. Advances in physiology education, 40(2), 147-56. http://doi.org/10.1152/advan.00138.2015

Lippman, L. H, Ryberg, R., Carney, R., Moore, K. A. (2015). Child Trend:. Workforce Connections: Key "Soft Skills" That Foster Youth Workforce Success: Toward A Consensus Across Fields. https://www.usaid.gov/sites/default/files/documents/1865/KeySoftSkills.pd f.

Liventsova, E., Rumyantsevaa, T., \& Syriamkina, E. (2016). Development of Social and Entrepreneurial Skills of Students of Engineering and Technical Specialties In The Modern University. Proceeding MATEC Web of Conferences (Vol. 7, pp. 19). http:// doi.org/10.1051/matecconf/201679010

Marando, A. (2012). Balancing Project Management Hard Skill and Soft Skills. Massachusetts, USA: Braindeis University.

Md-Ali, R., Shaffie, F., \& Yusof, M. F. (2016). Understandings and Conceptions of Soft Skills for Educators in Public Universities. Future Academy: The European Proceedings of Social \& Behavioural Sciences, 694-701.

Novikova, N. (2016). Competitiveness of Students in the Culture Sphere in the Modern Educational Space. SHS Web of Conferences, 9, 1-4. http://doi.org/10.1051/shsconf/20162902031

Patacsil, F. F., \& Tablatin, C. L. S. (2017). Exploring the Importance of Soft and Hard Skills as Perceived by It Internship Students and Industry: A Gap Analysis. Journal of Technology and Science Education, 7(3), 347-368. https:// doi.org/10.3926/jotse.271 
Rajadurai, J., Sapuan, N. M., Daud, S., Salina, D., \& Abidin, N (2018). The Marketability of Technical Graduates from Higher Educational Institutions (HEIs) Offering Technical and Vocational Education and Training (TVET): A Case from Malaysia. Asia-Pacific Edu Res. 27(137), 535-543. https://doi.org/10.1007/s40299-018-0372-7

Setiawan, T. W., Qonita, A. B., Asna, Arna, A., Khaidir, M., Wahab. A., Rifa, M. J., Rozikan, M., Mufid, A., Fahmi, K., Purwanto, A., \& Muhaini. A. (2020). Effect of Hard Skills, Soft Skills, Organizational Learning and Innovation Capability on Islamic University Lecturers' Performance. Sys Rev Pharm, 11(7), 556-569.

The Ontario Public Services. (2016). Towards Defining 21st Century Competencies for Ontario. Ontario, Canada: Ontario Public Service.

Universitas Indonesia-UPI. (2020). Panduan Implementasi Merdeka Belajar - Kampus Merdeka Universitas Pendidikan Indonesia. Bandung, Indonesia: Universitas Pendidikan

Indonesia. http://cs.upi.edu/v2/assets/docs/Panduan_MBKM_UPI.pdf.

Universitas Jambi-UNJA. (2020). Strategic Plan of University of Jambi. https://lppm.unja.ac.id/wp-content/uploads/2021/01/RENSTRA-UNJA-

SMART-2.pdf 